Cilt/Volume:14 Sayı/Issue:1 Ocak/January 2022

\title{
Beton ve Mermer Atıkları Kullanılarak Üretilen Bitümlü Sıcak Karışımların Optimum Bitüm Miktarının Bulanık Mantık Yöntemi ile Tahmin Edilmesi
}

\author{
Estimating the Optimum Bitumen Amount of Hot Bituminous Mixtures Produced \\ Using Concrete and Marble Wastes by Fuzzy Logic Method
}

\author{
*Erdinç Halis Alakara1 ${ }^{1 D}$, Melih Naci Ağaoğlu 1 \\ ${ }^{I}$ Tokat Gaziosmanşa Üniversitesi Mühendislik ve Mimarlık Fakültesi İnşaat Mühnedisliği Bölümü, 60000 Tokat, Türkiye
}

Başvuru/Received: 22/04/2021

Kabul / Accepted: 29/08/2021

Çevrimiçi Basım / Published Online: 31/01/2022

Son Versiyon/Final Version: 31/01/2022

\begin{abstract}
Özet
Bu çalışmada, Marshall Tasarım Yöntemi kullanılarak 6 farklı asfalt karışımı hazırlanmıştır. Hazırlanan karışımlarda agrega olarak; beton atığı, mermer atığı ve kalker kökenli doğal agrega kullanılmıştır. Her bir karışım grubunda bitüm yüzdesi; \%3.5, \%4, \%4.5, $\% 5, \% 5.5, \% 6$ ve \%6.5 olmak üzere 7 farklı şekilde kullanılmıştır. Her bir bitüm yüzdesi için 3 adet olmak üzere toplamda 126 $(6 * 7 * 3)$ adet Marshall numunesi üretilmiştir. Karışımlar üretilirken Karayolları Teknik Şartnamesi 2013 (KTŞ 2013)’te binder tabakası için verilen kriterler göz önüne alınmıştır. Agrega gruplarının Marshall parametreleri ve optimum bitüm değerleri grafik yöntemiyle tespit edilmiştir. Sonrasında agrega efektif özgül ağırlığı ve bitüm yüzdesinin girdi olarak; pratik özgül ağırlığın ise çıtı olarak kullanıldığı bir bulanık mantık modeli geliştirilmişşir. Geliştirilen model sayesinde numunelere ait pratik özgül ağırlık değeri tahmin edilmiş ve buradan formül yardımıyla numunelere ait hava boşluğu yüzdesi değerleri hesaplanmıştır. Bu veriler yardımıyla "Hava Boşluğu-Bitüm Oranı" grafiği çizilmiş ve \%5 hava boşluğu değerine karşılık gelen değer optimum bitüm değeri olarak belirlenmiştir. Son olarak, deneysel çalışmadan ve bulanık mantık metodu yardımıyla tahmin edilen optimum bitüm değerleri kıyaslanmıştır. Deneysel ve tahmin sonuçlarından elde edilen verilerin birbirine oldukça yakın olduğu görülmüştür.
\end{abstract}

\section{Anahtar Kelimeler}

"Bitümlü sıcak karışım, bulanık mantık, optimum bitüm, geri dönüşüm, Marshall yöntemi, agrega özgül ağırlı̆ğ”

\begin{abstract}
In this study, 6 different asphalt mixtures were prepared using the Marshall Design Method. As aggregate in the prepared mixtures, concrete waste, marble waste and natural aggregate of limestone origin were used. Percentage of bitumen in each mixture group; It was used in 7 different ways as $3.5 \%, 4 \%, 4.5 \%, 5 \%, 5.5 \%, 6 \%$ and $6.5 \%$. A total of $126(6 * 7 * 3)$ Marshall samples were produced, 3 for each bitumen percentage. While producing the mixtures, the criteria given for the binder layer in the Highways Technical Specification 2013 (KTŞ 2013) were taken into consideration. Marshall parameters and optimum bitumen values of aggregate groups were determined by graphic method. Afterwards, aggregate effective specific gravity and bitumen percentage as input; A fuzzy logic model has been developed in which practical specific gravity is used as the output. Thanks to the developed model, the practical specific gravity value of the samples was estimated and the air void percentage values of the samples were calculated with the help of the formula. With the help of these data, the graph of "Air Void-Bitumen Ratio" was drawn and the value corresponding to 5\% air void value was determined as the optimum bitumen value. Finally, the optimum bitumen values estimated from the experimental study and with the help of fuzzy logic method were compared. It has been seen that the data obtained from the experimental and estimation results are quite close to each other.
\end{abstract}

Keywords

"Bituminous hot mix, fuzzy logic, optimum bitumen, recycling, Marshall method, aggregate specific gravity" 


\section{Giriş}

Dünyada ve ülkemizde karayolu inşaatında kullanılan en yaygın üstyapı çeşidi esnek üstyapılardır. Esnek üstyapıların en üst katmanı olan kaplama tabakasında, agrega ve bitümden oluşan bitümlü sıcak karışım (BSK) malzemesi kullanılmaktadır. Birçok inşaatın imalatında olduğu gibi üstyapı imalatında da agregalar oldukça yüksek miktarlarda kullanılmaktadır. BSK'nın yaklaşı $\% 95$ 'i agregadan, \%5'i de bitümden oluşmaktadır (Umar \& Ağar, 1991). Agregalar BSK'nın büyük bir kısmını oluşturduğu için karışımın performansını da önemli ölçüde belirlemektedir. Bu agregalar, genellikle doğal taş kaynaklarından elde edilmektedir. Fakat son yıllarda kaliteli agrega ocaklarına olan ihtiyacın artması, agrega temininde büyük sıkıntılar meydana getirmiştir. Bu sıkıntıların başında çevresel sorunlar gelmektedir. Doğal taş ocaklarından agrega çıkarma işlemi genelde patlatma yöntemiyle olduğu için bu durum ekolojik dengenin bozulmasına ve ocakların etrafındaki bitki örtüsünün yok olmasına neden olmaktadır. Tüm bu durumlar araştırmacıları, atık malzemelerin yeniden kullanımı üzerine incelemeler yapmaya yönlendirmiştir. Son yıllarda özellikle atık malzemelerin asfalt karışımlarında agrega olarak kullanımı ile ilgili çalışmalar oldukça hız kazanmıştır. Atık olarak ortaya çıkan cüruf, tuğla tozu, pirinç kabuğu, atık mermerler gibi endüstriyel atık malzemelerin BSK'da kullanılabilirliğinin araştırılmasıyla ilgili çalışmalar yapılmıştır.

Pota ocağı cürufunun BSK'larda filler agrega olarak kullanımının incelendiği çalışmada, pota ocağı cürufu içeren asfalt karışımların hacimsel ve mekanik özellikleri belirlenmiştir. Sonuç olarak pota ocağı cürufu içeren karışımların, kontrol numunelerine göre dolaylı çekme mukavemeti, hacimsel özellik ve tekrarlanan yüklere karşı direnç gibi durumlar açısından oldukça yüksek bir performans sağladığı tespit edilmiştir (Bocci, 2018). Diğer bir çalışmada ise tuğla tozunun mineral filler olarak BSK'larda kullanımı araştırılmıştır. Sonuçlar incelendiğinde, tuğla tozu ile hazırlanan karışımların, kontrol karışımlarına göre daha iyi bir mekanik özelliğe sahip olduğu görülmüş̧ür. Ayrıca tuğla tozunun, asfalt karışımların yorulma ömrünü ve nem hassasiyetini artırdığı, kalıcı deformasyonu ise önemli ölçüde azalttığı görülmüştür (Chen vd., 2011). BSK'larda pirinç kabuğu külünün filler agrega olarak kullanılmasının araştırıldığı bir diğer çalışmada ise pirinç kabuğu külünün \%50 oranında filler agregaya ikame edilmesi durumunda en yüksek stabiliteyi verdiği ve BSK'larda kullanımının uygun olduğu tespit edilmiş̧tir (Sargın vd., 2013). Atık mermerlerin BSK'nın binder tabakasında kullanımının incelendiği çalışmada; atık mermer katkılı ve katkısız Marshall numuneleri üretilmiş ve sonuç olarak mermer atı̆g ile üretilen karışımların hafif ve orta hacimli trafiğe maruz kalan kaplamaların binder tabakasında kullanılabileceği görülmüştür (Gürer, 2005).

Yapılan araştırmalar sonucunda, tüm dünyada oluşan katı atıkların neredeyse yarısının inşaat sektöründen kaynaklandığı görülmüştür. Katı atıkların yaklaşı \% \%"'ının inşaat ve yıkıntı atıklarından, bunun ise \%50-60 oranında beton atıklarından oluştuğu tahmin edilmektedir (Maçin \& Demir, 2018). Katı atıkların çok fazla olduğu bir diğer sektör ise mermer madenciliğidir. Mermer madenciliğinde, ocaktan çıkarma ve tesislerde işleme sırasında oldukça büyük miktarlarda atıklar oluşmaktadır. Mermerlerin ocaktan çıkarılması sırasında $\% 50$ civarında atık meydana gelirken, tesislerde işleme sırasında $\% 20$ civarında atık mermer parçaları oluşmaktadır (Alakara, 2020). Oluşan bu atıkların uygun bir şekilde geri dönüştürülmesi ile özellikle yol inşaatı gibi agreganın oldukça yoğun kullanıldığı kısımlarda kullanımının uygun olacağı düşünülmektedir. Bu sayede hem ekonomik açıdan hem de çevresel açı1dan büyük katkı sağlanacaktır.

Literatür çalışmaları incelendiğinde, BSK'lara ait bazı parametre değerlerinin bulanık mantık metodu ile tahmin edilebildiği görülmüştür. BSK'nın rijitliğinin Shell metoduna göre incelendiği çalışmada; bulanık mantık yaklaşımı kullanılarak bir tahmin modeli oluşturulmuştur. Sonuç olarak bulanık mantık yaklaşımından elde edilen değerlerin Shell metoduna göre hesaplanan değerlere oldukça yakın olduğu belirlenmiştir (Sayın \& Tanyıldızı, 2006). BSK numunelerine ilave edilen polimer yüzdesi ve kırılma yüzdesine bağlı olarak Marshall stabilite değerlerinin tahmin edildiği çalışmada; deneysel ve tahmin sonuçları karşılaştırıldığında \%5.12'lik bir hata oranıyla stabilite değerlerinin tahmin edilebildiği görülmüştür (Zehtabchi vd., 2018). Bulanık mantıkla ilgili yapılan diğer bir çalışmada ise genleştirilmiş kil kullanılarak üretilen hafif asfalt karışımların Marshall stabilitesi tahmin edilmiştir. Çalışmada girdi olarak birim hacim ağırlık, bitüm miktarı ve ultrases geçiş hızı değerleri; çıktı olarak ise stabilite değeri girilmiştir. Sonuç olarak Marshall stabilite değerlerinin çok yüksek bir doğrulukla tahmin edilebildiği görülmüştür (Serin vd., 2013).

Normal uygulamada BSK'ların optimum bitüm değerinin tespit edilebilmesi için Marshall deneyi kullanılmaktadır. Bu deney hem yorucu hem de zaman alıcıdır. Literatür araştırmaları, optimum bitümün bulanık mantık metodu kullanılarak tahmin edilmesine yönelik kısıtlı sayıda çalışmaların bulunduğunu göstermektedir. Literatürdeki bu eksiklik göz önüne alınarak yapılan bu çalışmada bir bulanık mantık modeli kurulmuştur. Modelde, agrega karışımlarına ait efektif özgül ağırlık değerleri ve bitüm miktarları girdi olarak; pratik özgül ağırlık değeri ise çıktı olarak kullanılmıştır. Daha sonra tahmin edilen pratik özgül ağırlık değerleri yardımıyla hava boşluğu yüzdesi değerleri belirlenmiş ve buradan da her bir gruba ait optimum bitüm miktarları tahmin edilmiştir. Son olarak bulanık mantık modeli kullanılarak elde edilen tahmin verileri deneysel veriler ile kıyaslanmıştır. Çalışma sayesinde; herhangi bir deneysel işlem gerçekleştirmeden, çok kısa bir sürede ve çok yüksek bir doğruluk oranıyla optimum bitüm oranının tespit edilebileceği görülmüştür.

\section{Deneysel Program}

\subsection{Materyal}

2.1.1. Bitüm

Çalışma kapsamında 50/70 penetrasyon sınıfına sahip bitüm kullanılmıştır. Kullanılan bitüme ait fiziksel özellikler Tablo 1'de verilmiştir. 
Tablo 1. Bitümün fiziksel özellikleri

\begin{tabular}{ccc}
\hline Test & Deney sonucu & Standart \\
\hline Penetrasyon $\left(25^{\circ} \mathrm{C}\right)$ & 58 & TS EN 1426 \\
Yumuşama Noktası $\left({ }^{\circ} \mathrm{C}\right)$ & 50 & TS EN 1427 \\
Özgül ağırlık $\left(\mathrm{gr} / \mathrm{cm}^{3}\right)$ & 1.036 & TS 1013 EN ISO 3675 \\
Düktilite $\left(25^{\circ} \mathrm{C}, 5 \mathrm{~cm} / \mathrm{min}\right)$ & $>100$ & TS EN 13589 \\
Parlama Noktası $\left({ }^{\circ} \mathrm{C}\right)$ & 302 & TS EN ISO 2592 \\
\hline
\end{tabular}

\subsubsection{Agrega}

Çalışmadaki agrega karışımlarında; kalker kökenli doğal agrega, atık mermer ve atık beton agregası olmak üzere 3 farklı agrega tipi, farklı boyut ve yüzdelerde kullanılmıştır. Bu karışımlara ait bilgiler Tablo 2'de gösterilmiştir. Atık mermer ve atık betonlar laboratuvar tipi çeneli kırıcı ile belirli boyutlara getirilmiştir. Agregalara ait fiziksel özelikler Tablo 3 'te verilmiştir. Çalışma kapsamında, binder tabakasına uygun olarak hazırlanan agrega gradasyonu Şekil 1'de gösterilmiştir. Şekil 1'de elde edilen agrega gradasyonunda agrega karışımının; \%58.6'sı kaba agrega, \%36.7'si ince agrega ve \%4.7'si filler agregadan oluşmaktadır.

Tablo 2. Agrega gruplarının karışım oranları

\begin{tabular}{ccccccc}
\hline \multirow{2}{*}{$\begin{array}{c}\text { Grup } \\
\text { Adı }\end{array}$} & \multicolumn{2}{c}{ Kaba Agrega $(\%)$} & \multicolumn{2}{c}{ Ince Agrega $(\%)$} & $\begin{array}{c}\text { Filler } \\
(\%)\end{array}$ & $\begin{array}{c}\text { Toplam } \\
(\%)\end{array}$ \\
\cline { 2 - 5 } & Doğal & $\begin{array}{c}\text { Mermer } \\
\text { Atı̆̆ }\end{array}$ & Doğal & $\begin{array}{c}\text { Beton } \\
\text { Atı̆̆ }\end{array}$ & Doğal & \\
\hline 1 & 58.6 & - & 36.7 & - & 4.7 & 100 \\
2 & - & 58.6 & 36.7 & - & 4.7 & 100 \\
3 & - & 58.6 & 18.35 & 18.35 & 4.7 & 100 \\
4 & 58.6 & - & 18.35 & 18.35 & 4.7 & 100 \\
5 & - & 58.6 & 27.53 & 9.17 & 4.7 & 100 \\
6 & 58.6 & - & 27.53 & 9.17 & 4.7 & 100 \\
\hline
\end{tabular}

Tablo 3. Agregaların fiziksel özellikleri

\begin{tabular}{|c|c|c|c|c|c|c|}
\hline \multirow[t]{2}{*}{ Malzeme özellikleri } & \multicolumn{3}{|c|}{ Doğal Agrega } & \multirow{2}{*}{$\begin{array}{r}\begin{array}{c}\text { Atık } \\
\text { Mermer }\end{array} \\
\text { Kaba }\end{array}$} & \multirow{2}{*}{$\begin{array}{r}\text { Beton Atığ } \mathbf{~} \\
\text { İnce }\end{array}$} & \multirow[t]{2}{*}{ Standart } \\
\hline & Kaba & İnce & Filler & & & \\
\hline Özgül ağırlık (gr/cm³) & 2.714 & 2.734 & 2.724 & 2.71 & 2.68 & TS EN 1097-6 \\
\hline Su emme $(\%)$ & 0.45 & 0.67 & - & 0.30 & 6.82 & TS EN 1097-6 \\
\hline $\begin{array}{l}\text { Los Angeles Aşınma } \\
\text { değeri }\end{array}$ & 20.65 & - & - & 20.78 & - & TS EN 1097-2 \\
\hline $\begin{array}{l}\text { Yassılık indeksi değeri } \\
(\%)\end{array}$ & 17.6 & - & - & 23.1 & - & BS 812 \\
\hline $\begin{array}{l}\text { Soyulma Mukavemeti } \\
(\%)\end{array}$ & $\begin{array}{l}\geq 60 \text { 'tan } \\
\text { fazla }\end{array}$ & - & - & $\geq 60^{\prime} \tan$ fazla & - & $\begin{array}{c}\text { KTŞ K1s } 403 \\
\text { Ek-A }\end{array}$ \\
\hline $\begin{array}{l}\text { Sıkışık Birim Hacim } \\
\text { Ağırlık }\left(\mathrm{g} / \mathrm{cm}^{3}\right)\end{array}$ & 1.54 & 1.86 & - & 1.48 & 1.55 & TS EN 1097-3 \\
\hline $\begin{array}{l}\text { Gevşek Birim Hacim } \\
\text { Ağırlık }\left(\mathrm{g} / \mathrm{cm}^{3}\right)\end{array}$ & 1.40 & 1.69 & - & 1.33 & 1.42 & TS EN 1097-3 \\
\hline
\end{tabular}

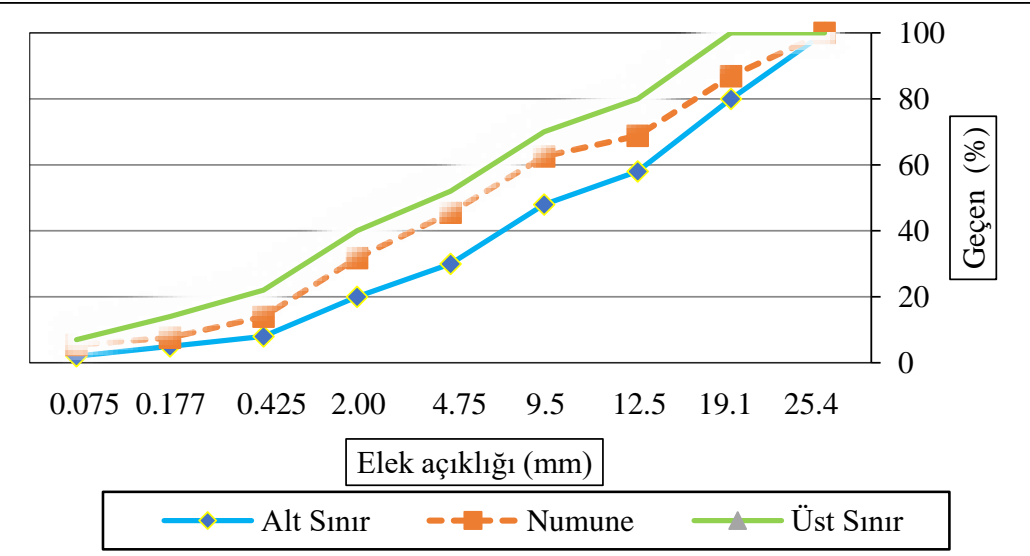

Şekil 1. Karışımlarda kullanılan agrega gradasyonu 


\subsection{Metot}

\subsubsection{Marshall tasarımı}

BSK numunelerinin hazırlanmasında Marshall Tasarımı Metodu kullanılmış̧ır. Çalışma kapsamında, Tablo 1'de verilen 6 farklı agrega karışımı ve 7 farklı bitüm oranı (\%3.5, \%4, \%4.5, \%5, \%5.5, \%6 ve \%6.5) kullanılarak Marshall numuneleri hazırlanmıştır. Agrega karışımının ağırlığı oranınca bitüm ilave edilmiş ve her bir bitüm oranında 3 adet numune üretilmiştir. Bu şekilde toplamda 126 (6x7 73 ) adet numune hazırlanmışıtır. Numuneler hazırlanırken; 1150 gram agrega karışımı tartılmış ve bitüm ile birlikte etüvde $155^{\circ} \mathrm{C}^{\prime}$ da yaklaşık bir gün 1sıtılmıştır. Etüvden alınan agrega ve bitüm terazide tartılmış ve alttan 1sıtıcılı mikserde karıştırılmıştır. Hazırlanan karışım önceden ısıtılımış ve yağlanmış kalıplara doldurularak Marshall tokmağı ile numunelerin her iki yüzüne 75 darbe uygulanmıştır. Son olarak numuneler oda sicaklığında soğutulmuştur (Alakara, 2020).

\subsubsection{Marshall parametrelerinin hesaplanmasl}

Marshall parametreleri şu şekilde belirlenmektedir: öncelikle numunenin havadaki ağırlı̆̆ı (A) belirlenir. Daha sonra numune suda bekletilerek doygun kuru yüzey ağılığı (B) tespit edilir. Son olarak sudaki ağırlık (C) belirlenerek buradan numunenin hacmi (V) hesaplanır. Ayrıca hava boşluğu $\left(V_{h}\right)$ değerinin hesaplanabilmesi için maksimum teorik özgül ağırlığın $\left(D_{T}\right)$ belirlenmesi gerekir. Bu değer agrega efektif özgül ağırlığı $\left(\mathrm{G}_{\mathrm{ef}}\right)$, numunede kullanılan bitüm yüzdesi $\left(\mathrm{W}_{\mathrm{a}}\right)$ ve bitümün özgül ağırlığına $\left(\mathrm{G}_{\mathrm{b}}\right)$ bağlı olarak hesaplanır. Marshall parametreleri Eşitlik 1, 2, 3 ve 4'te verilen formüller yardımıyla hesaplanır. Hazırlanan numunelerin, Marshall parametreleri belirlendikten sonra pratik özgül ağırlık $\left(D_{P}\right)$, stabilite, akma, agregalar arası boşluk (VMA), asfalt ile dolu boşluk $\left(\mathrm{V}_{\mathrm{f}}\right)$ ve hava boşluğu $\left(\mathrm{V}_{\mathrm{h}}\right)$ grafikleri çizilerek optimum bitüm oranı hesaplanmıştır. Optimum bitüm miktarı, genellikle şartnamede verilen hava boşluğu limit değerlerinin ortalamasına karşılık gelen değer olarak alınmaktadır (Orhan, 2012). KTŞ 2013 binder tabakası için hava boşluğu limit değerlerini \%4-6 arasında kabul etmiştir (KTŞ, 2013). Ortalama hava boşluğu değerine (\%5) bağlı olarak belirlenen optimum bitüm değerine karşılık gelen diğer değerler grafikler yardımıyla hesaplanır ve şartnameye uygunluğu kontrol edilir.

$$
\begin{aligned}
& \mathrm{V}=\mathrm{B}-\mathrm{C} \\
& \mathrm{D}_{\mathrm{P}}=\frac{\mathrm{A}}{\mathrm{V}} \\
& \mathrm{D}_{\mathrm{T}}=\frac{100+\mathrm{W}_{\mathrm{a}}}{\frac{100}{\mathrm{G}_{\mathrm{ef}}}+\frac{\mathrm{W}_{\mathrm{a}}}{\mathrm{G}_{\mathrm{b}}}} \\
& \mathrm{V}_{\mathrm{h}}=\frac{\mathrm{D}_{\mathrm{T}}-\mathrm{D}_{\mathrm{P}}}{\mathrm{D}_{\mathrm{T}}} \times 100
\end{aligned}
$$

\subsubsection{Bulanık mantık}

Lotfi Zadeh tarafından 1965 yılında geliştirilen bulanık küme teorisi, belirsizlik konusu ile ilgilenen bir matematiksel araçtır (Zehtabchi vd., 2018). Model, hesapları kelimelerle ifade etme kavramını ortaya koymuştur. Model sayesinde, şüpheli kavramların veya belirsiz kümelerin elde edilmesi ve tanımlanması gerçekleştirilir. Ayrıca belirsizliklerin analizini kolaylaştıran bir modeldir. Son zamanlarda, bulanık mantık uygulamalarının sayısı büyük ölçüde artmıştır. Bu uygulamalar beyaz eşyalardan tıbbi uygulamalara kadar oldukça geniş bir alana yayılmıştır. Bulanık teori "az", "çok", "orta", "yüksek", "düşük" gibi dilsel yapıları temsil eden mekanizma sağlamaktadır (Kara \& Karacasu, 2017; Topçu vd., 2008; Topçu \& Sarıdemir, 2008 a; Topçu \& Sarıdemir, 2008 b; Kokoç, Ersöz \& Aktepe, 2020). Bulanık mantık sistemleri oldukça hızlı, sorunsuz ve kontrol karmaşıklığı çok az olan bir modeldir. Şekil 2'de bulanık mantık modeline ait temel öğeler gösterilmiştir.

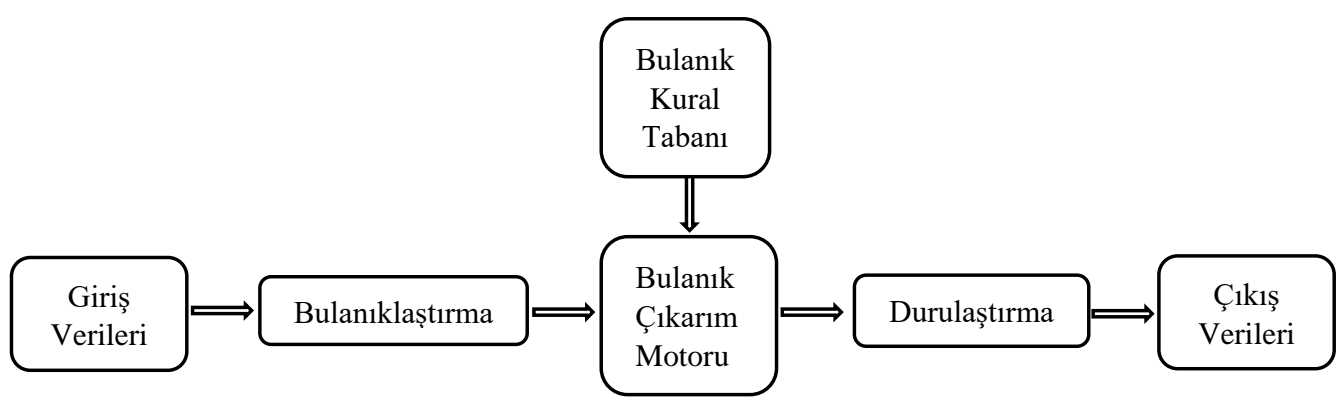

Şekil 2. Bulanık mantık modeline ait temel ögeler

Model genel olarak;

- Girdiler ve çıktılar arasındaki bulanık ilişkilere bağlı olarak "Eğer-Öyleyse" şeklinde oluşturulmuş bir bulanık kural tabanı,

- Bulanık kümelerin üyelik fonksiyonlarını tanımlayan veri tabanı,

- Kurallara bağlı olarak çıkarım işlemi yapan karar verme birimi, 
- Girdileri sözel ifadeye dönüştüren bulanıklaştırma arayüzü,

- Bulanık sonuçları net çıktıya dönüştüren bir durulaştırma arayüzünden oluşmaktadır [18].

\section{Deneysel Bulgular}

\subsection{Marshall Parametrelerinin Deneysel Olarak Belirlenmesi}

Çalışma kapsamında üretilen Marshall numunelerine ait parametreler deneyler sonucu belirlenmiştir. Optimum bitüm miktarı, her bir agrega karışım grubu için Şekil 3’te verilen "Hava Boşluğu - Bitüm Oranı” grafiğindeki, \%5 hava boşluğu değerine karşılık gelen değer olarak alınmıştır.

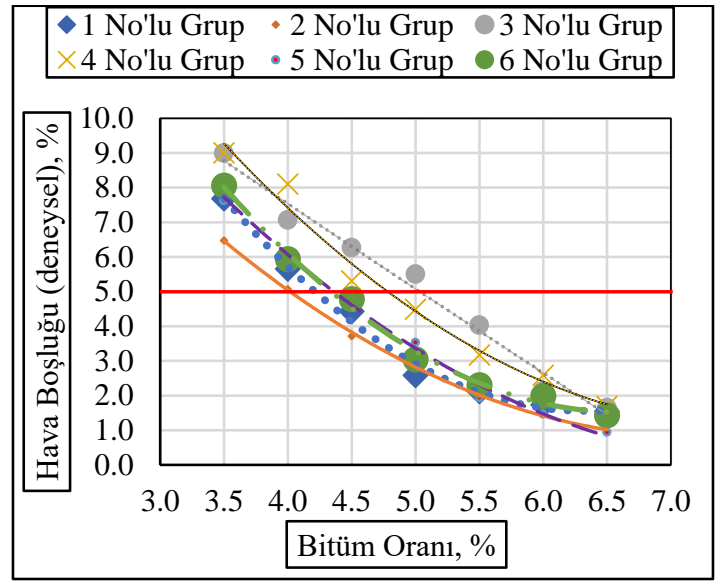

Şekil 3. "Hava boşluğu - bitüm oranı" grafiği

Her bir agrega grubuna ait optimum bitüm değeri belirlendikten sonra Tablo 4’te gösterildiği gibi optimum bitüm değerlerine karşıllk gelen stabilite, akma, asfaltla dolu boşluk ve agregalar arası boşluk değerlerinin şartname limitlerine uygunluğu kontrol edilmiştir. Tablo 4 incelendiğinde tüm gruplar için bu değerlerin şartname limitleri arasında kaldığ 1 görülmektedir. Tablo 5 'te ise Marshall numunelerine ait özgül ağırlık ve hava boşluğu değerleri gösterilmektedir. Bu parametreler belirlenirken Eşitlik 1-4'te verilen formüller kullanılmıştır.

Tablo 4. Optimum bitüm miktarına karşılık gelen Marshall parametreleri

\begin{tabular}{c|ccccccc}
\hline \multirow{2}{*}{$\begin{array}{c}\text { Karışım } \\
\text { Grupları }\end{array}$} & $\begin{array}{c}\text { Optimum } \\
\text { Bitüm } \\
(\%)\end{array}$ & $\begin{array}{c}\text { Pratik } \\
\text { Özgül } \\
\text { Ağırlık } \\
\left(\mathrm{g} / \mathrm{cm}^{3}\right)\end{array}$ & $\begin{array}{c}\text { Hava } \\
\text { boşluğu } \\
(\%)\end{array}$ & $\begin{array}{c}\text { Asfaltla Dolu } \\
\text { Boşluk (\%) }\end{array}$ & $\begin{array}{c}\text { Agregalar } \\
\text { Aras1 } \\
\text { Boşluk (\%) }\end{array}$ & $\begin{array}{c}\text { Stabilite } \\
(\mathrm{kg})\end{array}$ & $\begin{array}{c}\text { Akma } \\
(\mathrm{mm})\end{array}$ \\
\hline 1 & 4.20 & 2.410 & 5 & 64.44 & 13.89 & 1379 & 2.23 \\
2 & 4.02 & 2.419 & 5 & 63.31 & 13.51 & 1113 & 2.38 \\
3 & 5.03 & 2.347 & 5 & 64.54 & 14.10 & 1253 & 2.27 \\
4 & 4.78 & 2.352 & 5 & 63.17 & 13.48 & 1542 & 2.55 \\
5 & 4.35 & 2.387 & 5 & 63.23 & 13.47 & 1236 & 2.67 \\
6 & 4.33 & 2.386 & 5 & 62.98 & 13.33 & 1310 & 2.52 \\
Şartname & & & & & & & \\
Limitleri & & - & 4 & 60 & 13 & 750 & 2 \\
\hline min & - & - & 6 & 75 & 15 & - & 4 \\
max & - & - & & & & & \\
\hline
\end{tabular}

Tablo 4'te verilen deney sonuçları incelendiğinde, karışımlarda mermer agregası kullanılması durumunda stabilite değerlerinde düşüşler olduğu görülmektedir. Bu durumun mermer agregalarının yassılık indeksinin yüksek olmasından kaynaklı olduğu düşünülmektedir. Fakat bu düşüşler şartname sınır değerinin oldukça üzerinde kalmaktadır. Karışımlarda ince agrega olarak beton atığ1 kullanılması durumunda ise stabilite değerlerinde genel olarak bir artış elde edilmiştir. Mermer ve beton atıklarının bir arada kullanılmasıyla kontrol karışımlarının stabilite değerine yakın sonuçlar elde edilebileceği de tespit edilmiştir. Beton atığının poroz bir yapıda olması ise karışımların optimum bitüm miktarının artmasına sebep olmuştur. Ancak beton atığı ve mermer atıklarının çevreye verdiği zararlar göz önüne alındığında, bu artışların göz ardı edilebilir miktarda olduğu düşünülmektedir. Pratik özgül ağırlık değerleri incelendiğinde ise beton atıklarının artmasıyla pratik özgül ağılık değerlerinin düştügü görülmüştür. Ayrıca beton atıklarının artması durumunda karışımların hava boşluğu değerleri artırmıştır. Bu durumların nedeninin de yine beton atıklarının poroz bir yapıya sahip olmasından kaynaklı olduğu düşünülmektedir. 
Tablo 5. Numunelere ait özgül ağırlık ve hava boşluğu değerleri

\begin{tabular}{|c|c|c|c|c|c|}
\hline \multirow{2}{*}{$\begin{array}{c}\text { Agrega } \\
\text { Karışım } \\
\text { Grubu }\end{array}$} & \multirow{2}{*}{$\begin{array}{c}\text { Bitüm } \\
\text { Oranı } \\
(\%)\end{array}$} & \multirow{2}{*}{$\underset{\left(\mathrm{g} / \mathrm{cm}^{3}\right)}{\mathbf{G}_{\text {ef }}}$} & \multirow{2}{*}{$\underset{\left(\mathrm{g} / \mathrm{cm}^{3}\right)}{\mathbf{D}_{\mathbf{T}}}$} & \multicolumn{2}{|c|}{ Deneysel Sonuçlar } \\
\hline & & & & $D_{P}\left(\mathrm{~g} / \mathrm{cm}^{3}\right)$ & $\mathrm{V}_{\mathrm{h}}(\%)$ \\
\hline \multirow{7}{*}{$\begin{array}{l}1 \text { No'lu } \\
\text { Grup }\end{array}$} & 3.5 & \multirow{7}{*}{2.703} & 2.564 & 2.367 & 7.68 \\
\hline & 4.0 & & 2.545 & 2.401 & 5.67 \\
\hline & 4.5 & & 2.528 & 2.416 & 4.41 \\
\hline & 5.0 & & 2.511 & 2.446 & 2.58 \\
\hline & 5.5 & & 2.494 & 2.441 & 2.13 \\
\hline & 6.0 & & 2.477 & 2.434 & 1.77 \\
\hline & 6.5 & & 2.461 & 2.423 & 1.54 \\
\hline \multirow{7}{*}{$\begin{array}{l}2 \text { No'lu } \\
\text { Grup }\end{array}$} & 3.5 & \multirow{7}{*}{2.704} & 2.564 & 2.398 & 6.48 \\
\hline & 4.0 & & 2.546 & 2.417 & 5.09 \\
\hline & 4.5 & & 2.529 & 2.435 & 3.70 \\
\hline & 5.0 & & 2.511 & 2.438 & 2.93 \\
\hline & 5.5 & & 2.495 & 2.446 & 1.94 \\
\hline & 6.0 & & 2.478 & 2.441 & 1.49 \\
\hline & 6.5 & & 2.462 & 2.438 & 0.96 \\
\hline \multirow{7}{*}{$\begin{array}{l}3 \text { No'lu } \\
\text { Grup }\end{array}$} & 3.5 & \multirow{7}{*}{2.655} & 2.522 & 2.295 & 8.98 \\
\hline & 4.0 & & 2.504 & 2.327 & 7.10 \\
\hline & 4.5 & & 2.488 & 2.332 & 6.26 \\
\hline & 5.0 & & 2.471 & 2.335 & 5.49 \\
\hline & 5.5 & & 2.455 & 2.356 & 4.02 \\
\hline & 6.0 & & 2.439 & 2.387 & 2.15 \\
\hline & 6.5 & & 2.424 & 2.384 & 1.65 \\
\hline \multirow{7}{*}{$\begin{array}{l}4 \text { No'lu } \\
\text { Grup }\end{array}$} & 3.5 & \multirow{7}{*}{2.654} & 2.521 & 2.294 & 8.98 \\
\hline & 4.0 & & 2.504 & 2.301 & 8.10 \\
\hline & 4.5 & & 2.487 & 2.355 & 5.29 \\
\hline & 5.0 & & 2.470 & 2.359 & 4.49 \\
\hline & 5.5 & & 2.454 & 2.376 & 3.20 \\
\hline & 6.0 & & 2.438 & 2.375 & 2.61 \\
\hline & 6.5 & & 2.423 & 2.382 & 1.68 \\
\hline \multirow{7}{*}{$\begin{array}{l}5 \text { No'lu } \\
\text { Grup }\end{array}$} & 3.5 & \multirow{7}{*}{2.680} & 2.544 & 2.350 & 7.62 \\
\hline & 4.0 & & 2.526 & 2.372 & 6.08 \\
\hline & 4.5 & & 2.509 & 2.389 & 4.78 \\
\hline & 5.0 & & 2.492 & 2.404 & 3.52 \\
\hline & 5.5 & & 2.475 & 2.427 & 1.95 \\
\hline & 6.0 & & 2.459 & 2.423 & 1.49 \\
\hline & 6.5 & & 2.443 & 2.420 & 0.96 \\
\hline \multirow{7}{*}{$\begin{array}{l}6 \text { No'lu } \\
\text { Grup }\end{array}$} & 3.5 & \multirow{7}{*}{2.678} & 2.542 & 2.337 & 8.04 \\
\hline & 4.0 & & 2.524 & 2.374 & 5.97 \\
\hline & 4.5 & & 2.507 & 2.387 & 4.79 \\
\hline & 5.0 & & 2.490 & 2.414 & 3.07 \\
\hline & 5.5 & & 2.474 & 2.417 & 2.28 \\
\hline & 6.0 & & 2.458 & 2.409 & 1.96 \\
\hline & 6.5 & & 2.442 & 2.407 & 1.44 \\
\hline
\end{tabular}

\subsection{Marshall Deney Sonuçlarının Bulanık Mantık Modeli ile Tahmini}

Bu çalışmada, MATLAB programı içerisinde yer alan Mamdani tipi Bulanık Mantık Çıkarım Sistemi (Fuzzy Inference System-FIS) kullanılarak Marshall parametrelerinden pratik özgül ağırlı $\left(D_{P}\right)$ değerleri tahmin edilmiştir. Oluşturulan modelde girdi verileri olarak agrega karışım gruplarının efektif özgül ağırlığı $\left(\mathrm{G}_{\mathrm{ef}}\right)$ ve bitüm oranı; çıktı olarak ise pratik özgül ağırlık $\left(\mathrm{D}_{\mathrm{P}}\right)$ değerleri kullanılmıştır. 126 adet Marshall numunesinden elde edilen veriler kullanılarak bu model oluşturulmuştur. Çalışma kapsamında oluşturulan bulanık mantık modeli Şekil 4'te gösterilmiştir. Modeldeki girdi ve çıktılara ait semboller Tablo 6'da; bu sembollere ait dilsel anlamlar da Tablo 7'de gösterilmiştir. Modele ait üyelik fonksiyonları ise Şekil 5'te gösterildiği gibidir. Üyelik fonksiyonları bazı kriterlere göre belirlenmiştir. BSK'larda binder tabakasındaki bitüm oranı değerleri KTŞ 2013'te \%3.5-6.5 arasında kalmaktadır. Bu nedenle bitüm oranına ait üyelik fonksiyonun sınır değerleri şartnamedeki sınır değerler dikkate alınarak belirlenmiştir. Karışımların efektif özgül 
ağırlık değerleri 2.654 ile 2.704 arasında değiştiği için efektif özgül ağılık değerlerinin üyelik fonksiyonlarının sınır değerleri bu aralık göz önüne alınarak belirlenmiştir. Deneysel çalışma sonucu elde edilen pratik özgül ağırlık değerleri ise 2.294 ile 2.446 arasında değiştiği için pratik özgül ağırlık değerlerinin üyelik fonksiyonlarının sınır değerleri de bu aralıkta seçilmiştir. Oluşturulan modelde toplamda 42 adet "Eğer-Öyleyse" kuralı oluşturulmuştur. Bu modelde pratik özgül ağırlık $\left(\mathrm{D}_{\mathrm{P}}\right)$ değerleri tahmin edildikten sonra Marshall numunelerine ait hava boşluğu yüzdesi $\left(V_{h}\right)$ değerleri Eşitlik 4 'te verilen formül yardımıyla dolaylı olarak hesaplanmıştır. Bu sayede hava boşluğu değerleri herhangi bir deney yapılmadan sadece agrega karışımının efektif özgül ağırlığı ve bitüm oranına bağlı olarak formül yardımıyla hesaplanmıştır.

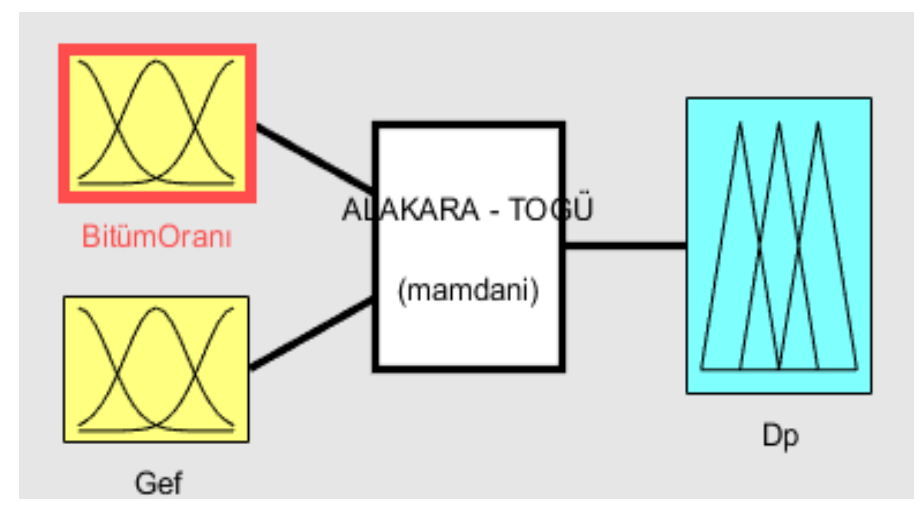

Şekil 4. Bulanık mantık modelinin genel yapısı

Tablo 6. Modelde kullanılan semboller

\begin{tabular}{lll}
\hline & Girdiler & \multicolumn{1}{c}{ Çıktı } \\
\hline $\begin{array}{l}\text { Bitüm } \\
\text { oran1, } \\
(\%)\end{array}$ & $\begin{array}{l}\text { Agrega karışımın } \\
\text { efektif özgül ağırlığ } \\
\left(\mathrm{g} / \mathrm{cm}^{3}\right)\end{array}$ & $\begin{array}{l}\text { Pratik özgül } \\
\text { ağılık }\left(\mathrm{g} / \mathrm{cm}^{3}\right)\end{array}$ \\
\hline B1 & $\mathrm{G}_{\mathrm{ef}} 1$ & $\mathrm{D}_{\mathrm{p}} 1$ \\
B2 & $\mathrm{G}_{\mathrm{ef}} 2$ & $\mathrm{D}_{\mathrm{p}} 2$ \\
B3 & $\mathrm{G}_{\mathrm{ef}} 3$ & $\mathrm{D}_{\mathrm{p}} 3$ \\
B4 & $\mathrm{G}_{\mathrm{ef}} 4$ & $\mathrm{D}_{\mathrm{p}} 4$ \\
B5 & $\mathrm{G}_{\mathrm{ef}} 5$ & $\mathrm{D}_{\mathrm{p}} 5$ \\
B6 & $\mathrm{G}_{\mathrm{ef}} 6$ & $\mathrm{D}_{\mathrm{p}} 6$ \\
B7 & & $\mathrm{D}_{\mathrm{p}} 7$ \\
& & $\mathrm{D}_{\mathrm{p}} 8$ \\
& & $\mathrm{D}_{\mathrm{p}} 9$ \\
\hline
\end{tabular}

Girdiler ve çıktılar için Tablo 6'da verilen sembollerin dilsel anlamı Tablo 7'de verilmiştir. "Eğer-Öyleyse" şeklinde oluşturulan modele ait kurallardan bazıları Şekil 6'da gösterilmiştir.

Tablo 7. Girdiler ve çıktı için sembollerin dilsel anlamı

\begin{tabular}{|c|c|c|}
\hline \multicolumn{2}{|c|}{ Girdiler } & \multirow[b]{2}{*}{ Dp1: Minimum } \\
\hline B1: Çok düşük & Gef1: Çok düşük & \\
\hline B2: Düşük & $\mathbf{G}_{\mathrm{ef} 2 \text { : Düşük }}$ & $\mathbf{D}_{\mathbf{p}}$ 2: Çok düşük \\
\hline B3: Düşük-Orta aras1 & $\mathbf{G}_{\mathrm{e}}$ 3: Düşük-Orta aras1 & Dp3: Düşük \\
\hline B4: Orta & Gef4: Orta & $\mathrm{D}_{\mathrm{p}}$ 4: Düşük-Orta aras1 \\
\hline B5: Orta-Yüksek arası & Gef5: Orta-Yüksek arası & $D_{\mathrm{p}} 5$ : Orta \\
\hline B6: Yüksek & $\mathbf{G}_{\text {ef6: }}$ Yüksek & D $\mathbf{p}$ : Orta-Yüksek aras1 \\
\hline \multirow[t]{3}{*}{ B7: Çok yüksek } & & Dp7: Yüksek \\
\hline & & Dp8: Çok yüksek \\
\hline & & Dp9: Maksimum \\
\hline
\end{tabular}


a)

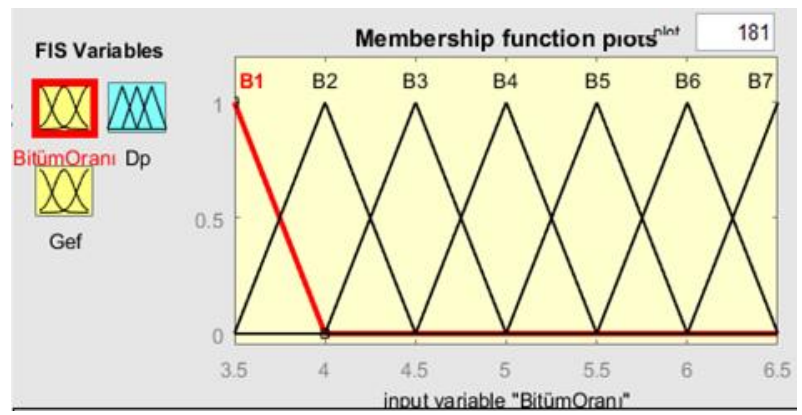

b)

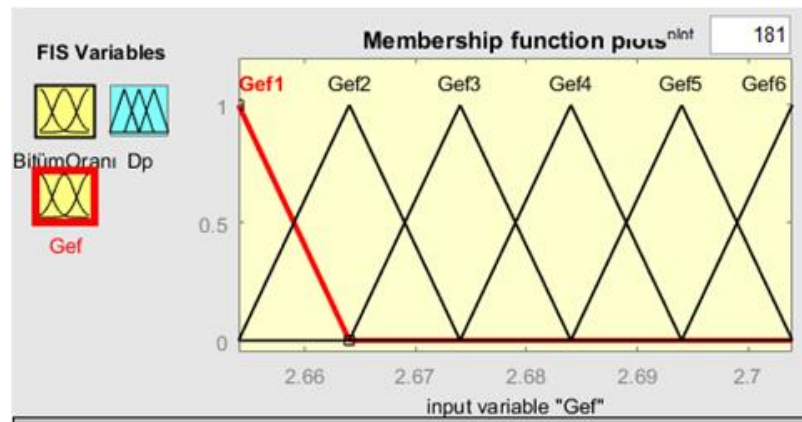

c)

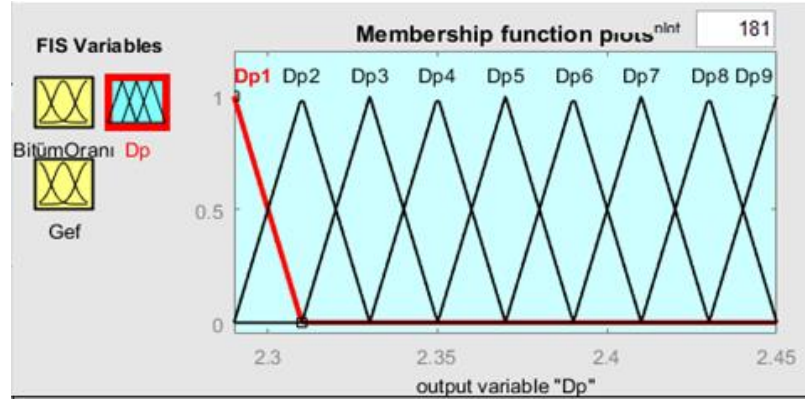

Şekil 5. Modele ait üyelik fonksiyonları; a) B, b) Gef, c) Dp

Bu modelde, 42 adet "Eğer-Öyleyse”" kuralı kullanılarak kural tabanı oluşturulmuştur. Modele ait kural örneği şu şekildedir:

Eğer (bitüm oranı B1) ve (efektif özgül ağırlık $G_{\text {ef }}$ 6) ise (pratik özgül ağırlık $D_{P} 5$ ) şeklindedir. Kural örneğinde bitüm ve agrega efektif özgül ağırlığı kısımlarına sayısal değerler girilmektedir. Tablo 8'de bulanık mantık modeli ile tahmin edilen $\mathrm{D}_{\mathrm{P}}$ değerleri ve Denklem 4'e göre hesaplanan $V_{h}$ değerleri gösterilmiştir.

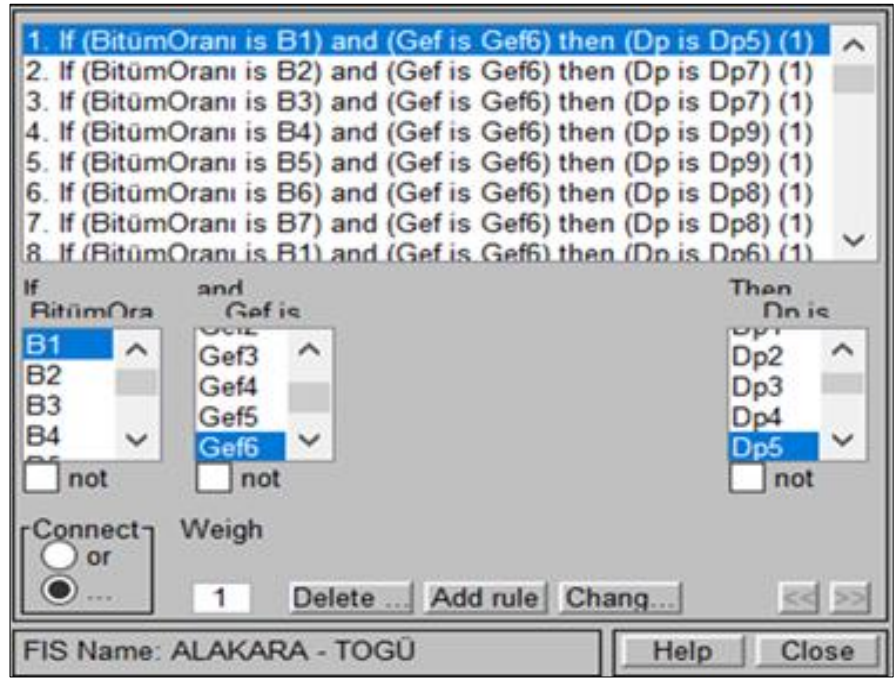

Şekil 6. Modele ait bazı kurallar 
Tablo 8. Bulanık mantık modeli ile tahmin edilen değerler

\begin{tabular}{|c|c|c|c|c|c|}
\hline \multirow{2}{*}{$\begin{array}{c}\text { Agrega } \\
\text { Karışım } \\
\text { Grubu }\end{array}$} & \multirow{2}{*}{$\begin{array}{l}\text { Bitüm Oran1 } \\
\quad(\%)\end{array}$} & \multirow{2}{*}{$\underset{\left(\mathrm{g} / \mathrm{cm}^{3}\right)}{\mathbf{G}_{\mathbf{e f}}}$} & \multirow{2}{*}{$\underset{\left(\mathrm{g} / \mathrm{cm}^{3}\right)}{\mathbf{D}_{\mathbf{T}}}$} & \multicolumn{2}{|c|}{ Tahmin Sonuçları } \\
\hline & & & & $\mathrm{D}_{\mathrm{P}}\left(\mathrm{g} / \mathrm{cm}^{3}\right)$ & $\mathrm{V}_{\mathrm{h}}(\%)$ \\
\hline \multirow{7}{*}{1 No'lu Grup } & 3.5 & \multirow{7}{*}{2.703} & 2.564 & 2.380 & 7.18 \\
\hline & 4.0 & & 2.545 & 2.410 & 5.30 \\
\hline & 4.5 & & 2.528 & 2.420 & 4.27 \\
\hline & 5.0 & & 2.511 & 2.434 & 3.07 \\
\hline & 5.5 & & 2.494 & 2.444 & 2.00 \\
\hline & 6.0 & & 2.477 & 2.433 & 1.78 \\
\hline & 6.5 & & 2.461 & 2.430 & 1.26 \\
\hline \multirow{7}{*}{2 No'lu Grup } & 3.5 & \multirow{7}{*}{2.704} & 2.564 & 2.380 & 7.18 \\
\hline & 4.0 & & 2.546 & 2.410 & 5.34 \\
\hline & 4.5 & & 2.529 & 2.420 & 4.31 \\
\hline & 5.0 & & 2.511 & 2.434 & 3.07 \\
\hline & 5.5 & & 2.495 & 2.444 & 2.04 \\
\hline & 6.0 & & 2.478 & 2.434 & 1.78 \\
\hline & 6.5 & & 2.462 & 2.430 & 1.30 \\
\hline \multirow{7}{*}{3 No’lu Grup } & 3.5 & \multirow{7}{*}{2.655} & 2.522 & 2.296 & 8.96 \\
\hline & 4.0 & & 2.504 & 2.320 & 7.35 \\
\hline & 4.5 & & 2.488 & 2.340 & 5.95 \\
\hline & 5.0 & & 2.471 & 2.350 & 4.90 \\
\hline & 5.5 & & 2.455 & 2.360 & 3.87 \\
\hline & 6.0 & & 2.439 & 2.380 & 2.42 \\
\hline & 6.5 & & 2.424 & 2.390 & 1.40 \\
\hline \multirow{7}{*}{4 No'lu Grup } & 3.5 & \multirow{7}{*}{2.654} & 2.521 & 2.296 & 8.93 \\
\hline & 4.0 & & 2.504 & 2.320 & 7.35 \\
\hline & 4.5 & & 2.487 & 2.340 & 5.91 \\
\hline & 5.0 & & 2.470 & 2.350 & 4.86 \\
\hline & 5.5 & & 2.454 & 2.360 & 3.83 \\
\hline & 6.0 & & 2.438 & 2.380 & 2.38 \\
\hline & 6.5 & & 2.423 & 2.390 & 1.36 \\
\hline \multirow{7}{*}{5 No'lu Grup } & 3.5 & \multirow{7}{*}{2.680} & 2.544 & 2.350 & 7.63 \\
\hline & 4.0 & & 2.526 & 2.370 & 6.18 \\
\hline & 4.5 & & 2.509 & 2.390 & 4.74 \\
\hline & 5.0 & & 2.492 & 2.410 & 3.29 \\
\hline & 5.5 & & 2.475 & 2.420 & 2.22 \\
\hline & 6.0 & & 2.459 & 2.420 & 1.59 \\
\hline & 6.5 & & 2.443 & 2.410 & 1.35 \\
\hline \multirow{7}{*}{6 No'lu Grup } & 3.5 & \multirow{7}{*}{2.678} & 2.542 & 2.350 & 7.55 \\
\hline & 4.0 & & 2.524 & 2.370 & 6.10 \\
\hline & 4.5 & & 2.507 & 2.390 & 4.67 \\
\hline & 5.0 & & 2.490 & 2.410 & 3.21 \\
\hline & 5.5 & & 2.474 & 2.420 & 2.18 \\
\hline & 6.0 & & 2.458 & 2.420 & 1.55 \\
\hline & 6.5 & & 2.442 & 2.410 & 1.31 \\
\hline
\end{tabular}

Tablo 9'da deneysel ve tahmin sonuçlarına ait $\mathrm{D}_{\mathrm{P}}$ ile $\mathrm{V}_{\mathrm{h}}$ değerleri bir arada gösterilerek bu veriler arasındaki yüzdesel mutlak farklar gösterilmiştir. 
Tablo 9. Deneysel ve tahmin sonuçlarına ait yüzdesel farklar

\begin{tabular}{|c|c|c|c|c|c|c|}
\hline \multirow{2}{*}{$\begin{array}{c}\text { Agrega } \\
\text { Karışım } \\
\text { Grubu }\end{array}$} & \multicolumn{2}{|c|}{ Deneysel Sonuçlar } & \multicolumn{2}{|c|}{ Tahmin Sonuçları } & \multicolumn{2}{|c|}{$\begin{array}{c}\text { Yüzdesel Fark } \\
(\%)\end{array}$} \\
\hline & $D_{P}\left(\mathrm{~g} / \mathrm{cm}^{3}\right)$ & $\mathrm{V}_{\mathrm{h}}(\%)$ & $\mathrm{D}_{\mathrm{P}}\left(\mathrm{g} / \mathrm{cm}^{3}\right)$ & $\mathrm{V}_{\mathrm{h}}(\%)$ & $D_{P}\left(\mathrm{~g} / \mathrm{cm}^{3}\right)$ & $\mathrm{V}_{\mathrm{h}}(\%)$ \\
\hline \multirow{7}{*}{$\begin{array}{l}1 \text { No'lu } \\
\text { Grup }\end{array}$} & 2.367 & 7.68 & 2.380 & 7.18 & 0.55 & 6.51 \\
\hline & 2.401 & 5.67 & 2.410 & 5.30 & 0.37 & 6.53 \\
\hline & 2.416 & 4.41 & 2.420 & 4.27 & 0.17 & 3.17 \\
\hline & 2.446 & 2.58 & 2.434 & 3.07 & 0.49 & 18.99 \\
\hline & 2.441 & 2.13 & 2.444 & 2.00 & 0.12 & 6.10 \\
\hline & 2.434 & 1.77 & 2.433 & 1.78 & 0.04 & 0.56 \\
\hline & 2.423 & 1.54 & 2.430 & 1.26 & 0.29 & 18.18 \\
\hline \multirow{7}{*}{$\begin{array}{l}2 \text { No'lu } \\
\text { Grup }\end{array}$} & 2.398 & 6.48 & 2.380 & 7.18 & 0.75 & 10.80 \\
\hline & 2.417 & 5.09 & 2.410 & 5.34 & 0.29 & 4.91 \\
\hline & 2.435 & 3.70 & 2.420 & 4.31 & 0.62 & 16.49 \\
\hline & 2.438 & 2.93 & 2.434 & 3.07 & 0.16 & 4.78 \\
\hline & 2.446 & 1.94 & 2.444 & 2.04 & 0.08 & 5.15 \\
\hline & 2.441 & 1.49 & 2.434 & 1.78 & 0.29 & 19.46 \\
\hline & 2.438 & 0.96 & 2.430 & 1.30 & 0.33 & 35.42 \\
\hline \multirow{7}{*}{$\begin{array}{l}3 \text { No'lu } \\
\text { Grup }\end{array}$} & 2.295 & 8.98 & 2.296 & 8.96 & 0.04 & 0.22 \\
\hline & 2.327 & 7.10 & 2.320 & 7.35 & 0.30 & 3.52 \\
\hline & 2.332 & 6.26 & 2.340 & 5.95 & 0.34 & 4.95 \\
\hline & 2.335 & 5.49 & 2.350 & 4.90 & 0.64 & 10.75 \\
\hline & 2.356 & 4.02 & 2.360 & 3.87 & 0.17 & 3.73 \\
\hline & 2.387 & 2.15 & 2.380 & 2.42 & 0.29 & 12.56 \\
\hline & 2.384 & 1.65 & 2.390 & 1.40 & 0.25 & 15.15 \\
\hline \multirow{7}{*}{$\begin{array}{l}4 \text { No'lu } \\
\text { Grup }\end{array}$} & 2.294 & 8.98 & 2.296 & 8.93 & 0.09 & 0.56 \\
\hline & 2.301 & 8.10 & 2.320 & 7.35 & 0.83 & 9.26 \\
\hline & 2.355 & 5.29 & 2.340 & 5.91 & 0.64 & 11.72 \\
\hline & 2.359 & 4.49 & 2.350 & 4.86 & 0.38 & 8.24 \\
\hline & 2.376 & 3.20 & 2.360 & 3.83 & 0.67 & 19.69 \\
\hline & 2.375 & 2.61 & 2.380 & 2.38 & 0.21 & 8.81 \\
\hline & 2.382 & 1.68 & 2.390 & 1.36 & 0.34 & 19.05 \\
\hline \multirow{7}{*}{$\begin{array}{l}5 \text { No'lu } \\
\text { Grup }\end{array}$} & 2.350 & 7.62 & 2.350 & 7.63 & 0.00 & 0.13 \\
\hline & 2.372 & 6.08 & 2.370 & 6.18 & 0.08 & 1.64 \\
\hline & 2.389 & 4.78 & 2.390 & 4.74 & 0.04 & 0.84 \\
\hline & 2.404 & 3.52 & 2.410 & 3.29 & 0.25 & 6.53 \\
\hline & 2.427 & 1.95 & 2.420 & 2.22 & 0.29 & 13.85 \\
\hline & 2.423 & 1.49 & 2.420 & 1.59 & 0.12 & 6.71 \\
\hline & 2.420 & 0.96 & 2.410 & 1.35 & 0.41 & 40.63 \\
\hline \multirow{7}{*}{$\begin{array}{l}6 \text { No'lu } \\
\text { Grup }\end{array}$} & 2.337 & 8.04 & 2.350 & 7.55 & 0.56 & 6.09 \\
\hline & 2.374 & 5.97 & 2.370 & 6.10 & 0.17 & 2.18 \\
\hline & 2.387 & 4.79 & 2.390 & 4.67 & 0.13 & 2.51 \\
\hline & 2.414 & 3.07 & 2.410 & 3.21 & 0.17 & 4.56 \\
\hline & 2.417 & 2.28 & 2.420 & 2.18 & 0.12 & 4.39 \\
\hline & 2.409 & 1.96 & 2.420 & 1.55 & 0.46 & 20.92 \\
\hline & 2.407 & 1.44 & 2.410 & 1.31 & 0.12 & 9.03 \\
\hline
\end{tabular}

Tablo 9'da verilen deneysel ve tahmini " $D_{P}$ " değeri ile " $V_{h}$ " değeri arasındaki ilişki incelenmiştir. Deneysel ve tahmini değerler arasındaki ilişkiler Şekil 7'de gösterilmiştir. Burada verilen $\mathrm{R}^{2}$ değerleri deneysel ve tahmin verileri arasındaki ilişkiyi göstermektedir. $\mathrm{R}^{2}$ en fazla " 1 " değerini alabilmekte ve 1'e yaklaştıkça güvenilir sonuçlar alınmaktadır. Verilen grafikler incelendiğinde ise oldukça yüksek $\mathrm{R}^{2}\left(\mathrm{D}_{\mathrm{p}}: \% 95.79, \mathrm{~V}_{\mathrm{h}}: \% 97.86\right)$ değerlerinin elde edildiği görülmektedir. 
a)

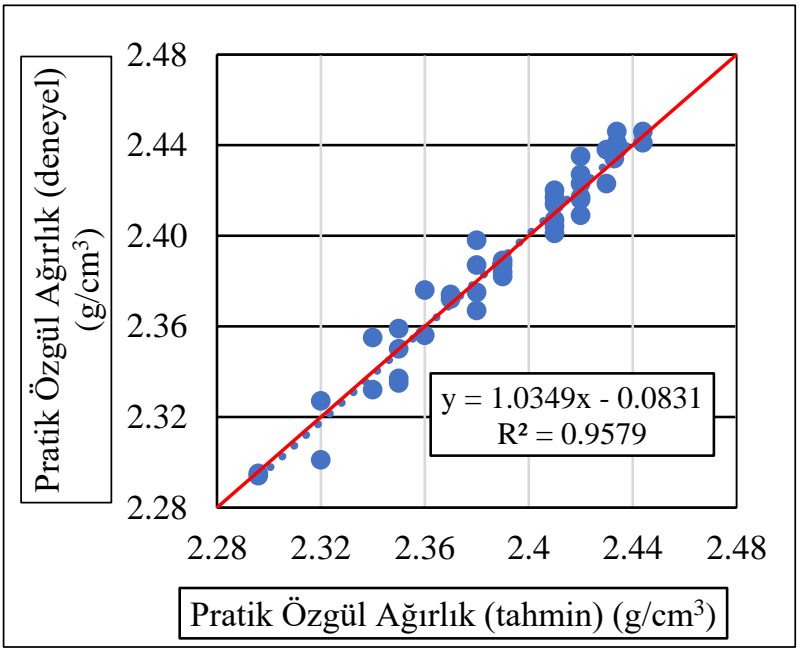

b)

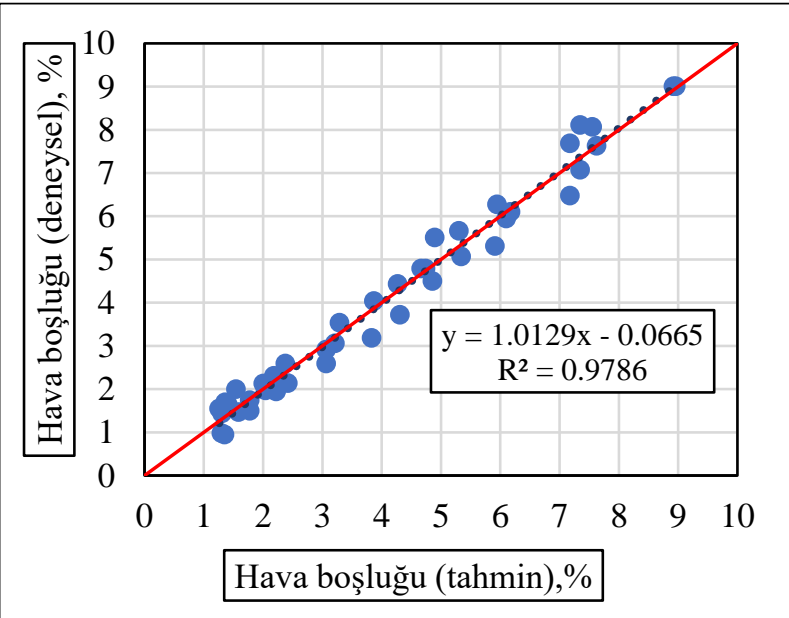

Şekil 7. Deneysel ve tahmin verileri arasındaki regresyon ilişkisi; a) Dp, b) Vh

Tablo 8'de verilen Vh değerlerine göre Şekil 8'de verilen “Hava Boşluğu - Bitüm Oranı” grafiği çizilmiştir. Daha sonra KTŞ 2013'e göre $\% 5$ hava boşluğu değerine karşılık gelen değer optimum bitüm miktarı olarak kabul edilmiş ve Tablo 10’da verilen değerler optimum bitüm olarak bulunmuştur.

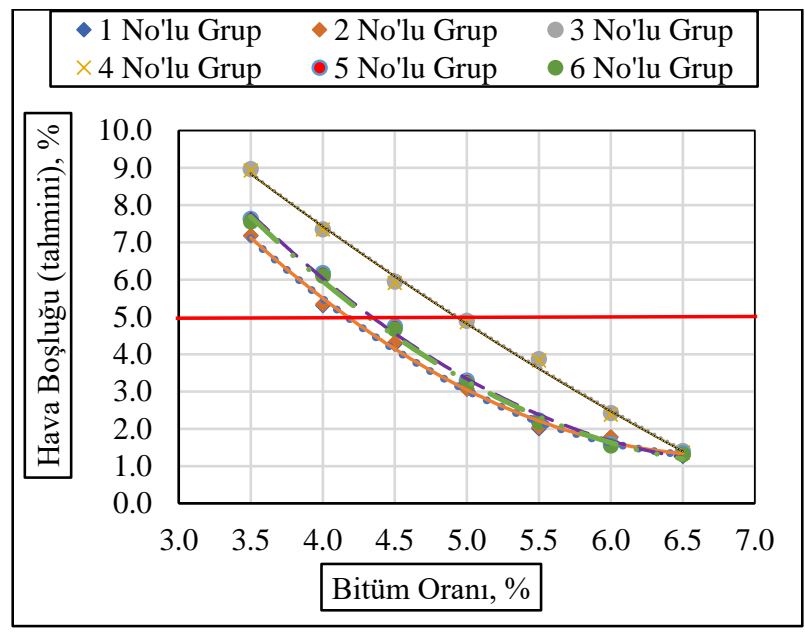

Şekil 8. Tahmini hava boşluğu - bitüm oranı grafiği 
Tablo 10. Deneysel ve tahmini optimum bitüm oranları

\begin{tabular}{ccc}
\hline Numune Grup No & \multicolumn{2}{c}{ Optimum Bitüm Oranı (\%) } \\
\hline & Deneysel & Tahmini \\
\hline 1 No'lu Grup & 4.20 & 4.17 \\
2 No'lu Grup & 4.02 & 4.16 \\
3 No'lu Grup & 5.03 & 4.94 \\
4 No'lu Grup & 4.78 & 4.92 \\
5 No'lu Grup & 4.35 & 4.34 \\
6 No'lu Grup & 4.33 & 4.32 \\
\hline
\end{tabular}

Son olarak deneysel ve tahmini bitüm değerleri arasındaki ilişkiyi daha iyi görebilmek için Şekil 9'da verilen grafik çizilmiştir.

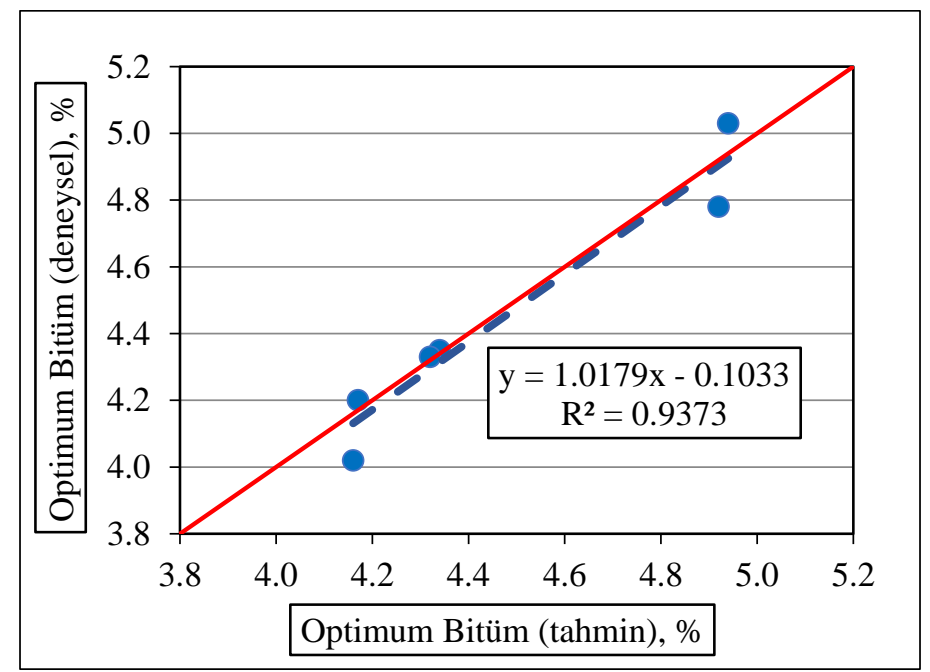

Şekil 9. Deneysel ve tahmini optimum bitüm değerleri arasındaki regresyon ilişkisi

Şekil 9'daki grafik incelendiğinde, $\mathrm{R}^{2}$ değerinin 0.9373 olarak bulunduğu görülmektedir. Buradaki denklem kullanılarak yapılan tahminlerde, 1'e oldukça yakın olduğu tespit edilen $\mathrm{R}^{2}$ değeri dikkate alındığında, bulunan optimum bitüm değerlerinin anlamlı olduğu görülmektedir.

\section{Sonuçlar}

Bu çalışmada, BSK'ların optimum bitüm oranı bulanık mantık yaklaşımıyla tahmin edilmiştir. Çalışmada, Marshall Tasarım Yöntemi kullanılarak asfalt numuneleri üretilmiştir. Ayrıca üretilen numunelerde mermer ve beton atıkları kullanılmış ve bu atıkların BSK'larda kullanılabilirliği araştırılmıştır. Yapılan çalışma sonucunda şu sonuçlar elde edilmiştir:

- Karışımlarda atık mermer kullanılması durumunda stabilite değerlerinde bir azalış olduğu tespit edilmiş̧ir. Bu düşüşün mermer agregalarının yassılık indeksi değerinin yüksek olmasından kaynaklı olduğu düşünülmektedir. Ancak bu azalışa rağmen numuneler şartnamede verilen minimum stabilite değerinin $(750 \mathrm{~kg})$ oldukça üzerinde kalmıştır. Şehir içi yollarda ve trafiğin az olduğu yollarda atık mermer kullanımının uygun olabileceği ve bu şekilde atık haldeki malzemelerin de bertaraf edilebileceği düşünülmektedir. Ayrıca karışımlarda mermer ve beton atıklarının birlikte kullanılması durumunda, şahit numunelerin stabilite değerlerine oldukça yakın bir sonuç elde edilebileceği görülmektedir.

- Sonuçlar incelendiğinde, karışımlar içerisindeki beton atığı miktarının artması ile stabilitenin arttığı görülmektedir. Ancak beton atığının artması optimum bitüm miktarını da bir miktar artırmıştır. Fakat beton atıklarının çevreye verdiği zarar ve depolama maliyetleri düşünüldüğünde bu artışın göz ardı edilebilecek düzeyde olduğu düşünülmektedir.

- Deneysel sonuçlar ile oluşturulan bulanık mantık modeline göre tahmin edilen değerler arasındaki ilişkiyi gösteren grafikler Şekil 7 ve Şekil 9'da gösterildiği gibi çizilmiştir. Grafikler incelendiğinde $D_{p}, V_{h}$ ve optimum bitüm oranına ait $R^{2}$ değerlerinin sırasıyla \%95.79, \%97.86, \%93.73 olarak bulunduğu, bu değerlerin 1'e oldukça yakın olduğu ve elde edilen tahminlerin anlamlı olduğu tespit edilmiştir.

Literatür çalışmaları incelendiğinde Marshall numunelerinin pratik özgül ağırlık değerlerinin, optimum bitüm miktarına olan etkisinin bulanık mantık modeli ile araştırılmasına dair çalışmalar oldukça kısıtlıdır. Bu çalışma sayesinde, numunelerin öncelikle pratik özgül ağırlık değerleri bulanık mantık yöntemiyle tahmin edilmiştir. Daha sonra denklemler yardımıyla hava boşluğu değerleri bulunmuştur. Elde edilen hava boşluğu değerleri kullanılarak "hava boşluğu-bitüm oranı" grafiği çizilmiştir. Son olarak \%5 hava boşluğu değerine 
karşılık gelen bitüm oranları her bir grup için optimum bitüm oranı olarak belirlenmiştir. Böylece pratik özgül ağırlık değerlerinin optimum bitüm miktarına olan etkisi bulanık mantık modeli kullanılarak incelenmiştir. Deneysel sonuçlardan elde edilen optimum bitüm oranı değerleri ile tahmin edilen optimum bitüm oranı değerlerinin birbirine yakın sonuçlar verdiği görülmüştür.

Optimum bitüm miktarının sadece agrega özgül ağırlık değerine bağlı olmadı̆̆ı, sıcaklık ve bitüm özellikleri gibi parametrelere de bağlı olduğu bilinmektedir. Bu nedenle sonraki çalışmalarda bu gibi kriterlerin de dikkate alınmasında fayda olacağı düşünülmektedir. Ayrıca gelecek çalışmalarda mermer ve beton atıklarının ekonomikliği ile ilgili bir maliyet analizi yapılmasının faydalı olacağı düşünülmektedir.

\section{Referanslar}

Akkurt S, Tayfur G \& Can S. (2004). "Fuzzy logic model for the prediction of cement compressive strength" Construction and Building Materials, 34(8), 1429-1433. doi.org/10.1016/j.cemconres.2004.01.020

Alakara E. H. (2020). Tokat İli Mermer İşletmelerinde Ortaya Çıkan Atık Mermerlerin ve Kentsel Dönüşüm Beton Atıklarının Bitümlü Sıcak Karışımlarda Kullanımının İncelenmesi. Yüksek Lisans Tezi, Tokat Gaziosmanpaşa Üniversitesi, Tokat.

Bocci E. (2018). "Use of ladle furnace slag as filler in hot asphalt mixtures". Construction and Building Materials, 161 (2018), 156164, doi.org/10.1016/j.conbuildmat.2017.11.120

Chen M, Lin J, Wu S \& Liu C. (2011). "Utilization of recycled brick powder as alternative filler in asphalt mixture”. Construction and Building Materials, 25 (4), 1532-1536. doi.org/10.1016/j.conbuildmat.2010.08.005

Gürer C. (2005). Atık Mermer Parçalarının Bitümlü Yol Kaplamalarında Değerlendirilmesi. Yüksek Lisans Tezi, Afyon Kocatepe Üniversitesi, Afyon.

Kara Ç \& Karacasu M. (2017). "Investigation of waste ceramic tile additive in hot mix asphalt using fuzzy logic approach". Construction and Building Materials, 141 (2017), 598-607. doi.org/10.1016/j.conbuildmat.2017.03.025

Karayolları Genel Müdürlüğü. "Bitümlü Karışımlar Laboratuvarı Çalışmaları”. Ankara, 2012.

Karayolları Genel Müdürlüğü. "Karayolu Teknik Şartnamesi (KTŞ)”. Ankara, 2013.

Kokoç M., Ersöz S. \& Aktepe A. (2020). “A Fuzzy Inference System Proposal for Selecting Marketing Strategy”. International Journal of Eastern Anatolia Science Engineering and Design, 2(1), 1-21.

Maçin K. E. \& Demir İ. (2018). “Kentsel dönüşüm sürecinde İstanbul'da inşaat ve yıkıntı atıkları yönetimi”. ADYU Mühendislik Bilimleri Dergisi, 9 (2018), 188-201.

Sargin S, Saltan M, Morova N, Serin S \& Terzi S. (2013). "Evaluation of rice husk ash as filler in hot mix asphalt concrete". Construction and Building Materials, 48 (2013), 390-397. doi.org/10.1016/j.conbuildmat.2013.06.029

Sayın E \& Tanyıldızı H. (2006). "Bitümlü sıcak karışımların rijitliğinin bulanık mantık ile bulunması". Gazi Üniversitesi Mühendislik ve Mimarlık Fakültesi Dergisi, 21 (4), 645-649.

Serin S, Morova N, Sargin S, Terzi S \& Saltan M. "The fuzzy logic model for the prediction of marshall stability of lightweight asphalt concretes fabricated using expanded clay aggregate". Suleyman Demirel University Journal of Natural and Applied Science, 17(1), 163-172, 2013.

Topçu İ. B \& Sarıdemir M. (2008). "Prediction of mechanical properties of recycled aggregate concretes containing silica fume using artificial neural networks and fuzzy logic". Computational Materials Science, 42 (1), 74-82. doi.org/10.1016/j.commatsci.2007.06.011

Topçu İ. B \& Sarıdemir M. (2008). "Prediction of rubberized concrete properties using artificial neural network and fuzzy logic". Construction and Building Materials, 22(4), 532-540. doi.org/10.1016/j.conbuildmat.2006.11.007

Topçu İ. B, Karakurt C \& Sarıdemir M. (2008). "Predicting the strength development of cements produced with different pozzolans by neural network and fuzzy logic". Construction and Building Materials, 29 (10), 1986-1991. doi.org/10.1016/j.matdes.2008.04.005

Umar F Ağar E. Yol Üstyapısı. Birinci baskı. İstanbul, Türkiye, İ.T.Ü. İnşaat Fakültesi Matbaası, 1991. 
Zehtabchi A, Hashemi S. A. H \& Asadi S. (2018). "Predicting the strength of polymer-modified thin-layer asphalt with fuzzy logic". Construction and Building Materials, 169 (2018), 826-834. doi.org/10.1016/j.conbuildmat.2018.02.002 